\title{
A PRESUNÇÃO DE CONTRATO DE TRABALHO NA JURISPRUDÊNCIA: BREVES REFLEXÕES CRÍTICAS
}

\section{António Monteiro Fernandes*}

\begin{abstract}
SUMÁrIO: 1 . Um acórdão recente; 2. Da revista excepcional à presunção de laboralidade; 3. A evolução da noção legal de contrato de trabalho; 4. Ainda a questão da aplicação no tempo; 5. As excepções à regra; 6. O método tipológico; 7. A função da presunção; 8. A responsabilidade do legislador; 9. A evolução do pensamento legislativo; 10. Uma questão (também) de interpretação; 11. Primeiro caso: um tradutor de legendas; 12. Segundo caso: um instrutor de ginástica; 13. Terceiro caso: outro instrutor de ginástica; 14 . $\mathrm{O}$ argumento de "equilíbrio processual".
\end{abstract}

ReSumo: Partindo de um acórdão recente do STJ, relativo a um recurso de revisão excepcional, o estudo toma como objecto o problema - subjacente àquele acórdão - da aplicação no tempo da presunção de existência de um contrato de trabalho, estabelecida no artigo $12^{\circ}$ do Código do Trabalho. Discute-se no texto a jurisprudência, assente há anos no STJ, segundo a qual essa presunção só pode ser usada em litígios referentes a contratos celebrados antes da sua consagração legal.

Palavras-Chave: contrato de trabalho, qualificação, presunção, ónus da prova, aplicação no tempo.

AbSTraCt: Based on a recent STJ ruling, concerning an exceptional review appeal, the study takes as its object the problem underlying that ruling - of the application in time of the presumption of the existence of an employment contract, established in article 12 of the Code of Labor. The text discusses the jurisprudence, established for years in the STJ, according to which this presumption can only be used in disputes related to contracts entered into before its legal creation.

KEYWORDS: employment contract, qualification, presumption, burden of proof, application over time

\footnotetext{
* Professor na Faculdade de Direito da Universidade Lusófona Lisboa e na Faculdade de Direito da Universidade Nova de Lisboa. Investigador Integrado do CEAD - Francisco Suárez.
} 


\section{UM ACÓRDÃo RECENTE}

Já este ano, foi tirado no Supremo Tribunal de Justiça um importante acórdão ${ }^{1}$ que sugere, ainda que de modo um tanto lateral, a reposição de questões relacionadas com a aplicação do art. $12^{\circ}$ do Código do Trabalho, na parte em que estrutura a presunção de existência de um contrato de trabalho - questões essas que, apesar da existência de uma corrente jurisprudencial consolidada ${ }^{2}$, continuam a suscitar dúvidas desconfortáveis, nomeadamente em largo sector da doutrina.

É do seguinte teor a súmula do referido acórdão:

"1 - Não existe fundamento para a admissibilidade do recurso de revista excecional, nos termos do artigo 672..$^{\circ}$ n. ${ }^{\circ} 1$, alínea c), do Código de Processo Civil, quanto os casos concretos apreciados no Acórdão recorrido e no Acórdão-fundamento foram enquadrados em regimes normativos que na sua substância não são idênticos, pois no acórdão recorrido foi aplicada a LCT, lei que vigorava em $1 / 1 / 1999$, data da celebração do contrato, enquanto no acórdão fundamento, em que os contratos foram sucessivamente celebrados entre 5 de setembro de 2014 e 3 de fevereiro de 2017, foi aplicado o Código do Trabalho de 2009.

2 - Os critérios para a distinção entre contrato de trabalho e contrato de prestação de serviço são diferentes nos apontados regimes, desde logo, porque no regime do Código do Trabalho de 2009, que foi aplicado no caso concreto, apreciado no acórdão-fundamento, existe a presunção de contrato de trabalho, prevista no seu $\operatorname{art}^{\circ}{ }^{\circ} 12 .^{\circ}$, o que não se verifica no regime da LCT, aplicável ao caso concreto apreciado no acórdão recorrido.”

\section{DA REVISTA EXCEPCIONAL À PRESUNÇÃo DE LABORALIDAdE}

O recurso de revista excepcional, previsto no art. $672^{\circ}$ do Código do Processo Civil, é admissível quando um “acórdão da Relação esteja em

1 STJ 13/01/2021 - P. 13512/18.0T8LSB.L1.S1 (Сhambel Mourisco).

2 Veja-se, com informação muito detalhada e esclarecedora acerca dos fundamentos e da notável persistência desta corrente, STJ 07/04/2018 — Proc. 1272/16.4T8SNT.L1.S1 (Chambel MourisCo). 
contradição com outro, já transitado em julgado, proferido por qualquer Relação ou pelo Supremo Tribunal de Justiça, no domínio da mesma legislação e sobre a mesma questão fundamental de direito, salvo se tiver sido proferido acórdão de uniformização de jurisprudência com ele conforme" (al. c) do $\mathrm{n}^{\circ} 1$ do mesmo artigo). A excepcionalidade reporta-se aos casos de dupla conformidade, isto é - utilizando sempre as palavras do legislador - quando é emitido acórdão da Relação que confirme, sem voto de vencido e sem fundamentação essencialmente diferente, a decisão proferida na $1 .^{a}$ instância, casos cobertos pela regra de inadmissibilidade do recurso de revista, constante do $n .^{\circ} 3$ do art. $671^{\circ}$ do mesmo Código.

O acórdão a que se refere a presente anotação negou a revista excepcional, naturalmente com fundamento em considerações apontadas à demonstração da inexistência, no caso, de dupla conforme. E essa demonstração devia fazer-se, como no próprio acórdão se anota, pelo facto de ambas as decisões em jogo (o acórdão recorrido e o acórdão fundamento) incidirem "sobre a mesma questão fundamental de direito, devendo ser idêntico o núcleo da situação de facto, atenta a ratio da norma aplicável”, havendo "contradição ao nível da resposta dada em ambos os acórdãos" a essa mesma questão, e sendo esta considerada "essencial" para o resultado atingido por eles. Ademais, requer-se que as duas decisões em confronto assentem num "quadro jurídico idêntico", não relevando "alterações que não tenham alterado a sua substância".

Não podemos ter a veleidade de proceder à análise profunda, que o acórdão envolve, do "núcleo das situações de facto" consideradas nas duas decisões das Relações. O aresto do STJ baseou-se no entendimento de que elas eram diferentes, e eram-no realmente, mas talvez apenas em aspectos periféricos relativamente ao seu "núcleo". Este era inegavelmente preenchido por uma realidade cuja semelhança salta aos olhos independentemente de verificação mais funda: a da contratação, por uma instituição vocacionada para assegurar a prestação de serviços domiciliários a idosos e dependentes, de profissionais de uma categoria denominada "ajudantes familiares”, encarregados de realizar na prática esse tipo de serviços 
pessoais $^{3}$. É verdade que, nos dois casos considerados, essa realidade foi revestida de indumentárias distintas, criando a aparência de a "matéria de facto dada como provada no acórdão-fundamento apresentar um recorte diferente da matéria de facto dada como provada no acórdão recorrido", mas não parecendo que tal aparência bastasse para a afirmação de realidades nucleares diversas. Não é, porém, esse, repetimos, o terreno em que queremos situar as observações suscitadas pela decisão do Supremo.

Relativamente aos pressupostos propriamente jurídicos da admissibilidade (recusada) da revista excepcional, o acórdão em foco discorre assim:

"o quadro normativo aplicável a cada uma das situações não é, na sua substância, idêntico, pois no acórdão recorrido foi considerada a lei em vigor à data da celebração do contrato (1/10/1999), ou seja, a LCT, enquanto no acórdão fundamento foi aplicado, como já se referiu, o Código do Trabalho de 2009, pois no caso concreto os contratos foram sucessivamente celebrados entre 5 de setembro de 2014 e 3 de fevereiro de 2017".

Esta asserção, que se oferecia como a parede mestra da decisão, justificava-se nos seguintes termos (e aqui chegamos ao nosso ponto):

"Os critérios para a distinção entre contrato de trabalho e contrato de prestação de serviço são diferentes nos apontados regimes, desde logo, porque no regime do Código do Trabalho de 2009, que foi aplicado no caso concreto, apreciado no acórdão-fundamento, existe a presunção de contrato de trabalho, prevista no art. $^{\circ} 12 .^{\circ}$, o que não se verifica no regime da LCT, aplicável ao caso concreto apreciado no acórdão recorrido.”

Por outras palavras: a admissibilidade da revisão excepcional foi negada por faltar o requisito de nos dois acórdãos em confronto (o acórdão recorrido e o acórdão fundamento, ambos da Relação de Lisboa) se ter

3 A questão é simplificada (ou, a nosso ver, complicada) pela circunstância de existir um diploma legal sobre a matéria - o DL 141/89, de 28 de Abril - que pretendeu definir, nos termos do respectivo preâmbulo, "o tipo de relação jurídica que deve existir entre o ajudante familiar e a instituição responsável pela resposta social". Nos arts. $9^{\circ}$ e $10^{\circ}$, o diploma refere-se exclusivamente a uma possibilidade - a de "prestação de serviço" - , acautelando mesmo que, "pela celebração do contrato, os ajudantes familiares não adquirem a qualidade de empregado, funcionário ou agente das instituições de suporte". Note-se que estas injunções são declaradas aplicáveis, por igual, a instituições públicas e privadas. Levando as coisas à letra, estas últimas (as privadas) estariam impedidas de recrutar ajudantes familiares para os seus quadros de pessoal - consequência que, além de irrazoável, poderia até merecer censura constitucional. Acrescente-se que a contradição de julgados a que se refere o aresto citado, invocada em apoio da revisão excepcional, incide justamente sobre a questão da qualificação dos contratos envolvidos. 
decidido "no domínio da mesma legislação e sobre a mesma questão fundamental de direito", como consta do art. $672^{\circ}$ do Código do Processo Civil. E essa falta resultava de, num deles, se ter excluído a aplicação de qualquer presunção de laboralidade, por se tratar de contrato celebrado antes do Código de $2003^{4}$, e, no outro, se ter considerado a presunção estabelecida no art. $12^{\circ}$ do Código de 2009 , por estarem em causa contratos celebrados a partir de 2014 .

\section{A eVoluÇão da noção legal de Contrato de trabalho}

Com isto, aflorava no texto do acórdão uma concepção (ou, talvez antes, uma percepção) que qualificaríamos de "substantivista", acerca da natureza e da função que a chamada "presunção de laboralidade" desempenha no sistema de regras que têm por objecto a qualificação jurídica das relações de trabalho. Essa concepção traduz-se no entendimento de que a consagração da presunção (nas formulações de 2003, 2006 e 2009) envolveu uma alteração substantiva, incidente sobre "os critérios para a distinção entre contrato de trabalho e contrato de prestação de serviço", ou seja, sobre a própria configuração legal desses dois tipos negociais.

Na verdade, os "critérios" mencionados no aresto são os que hão-de reger a qualificação das situações concretas à luz das descrições dos tipos oferecidas pelo legislador, isto é, do conjunto dos elementos essenciais do contrato de trabalho e do contrato de prestação de serviço, tais como o legislador os desenhou para acolher e enquadrar juridicamente realidades diferentes. Dizer que os "critérios para a distinção" desses dois tipos contratuais mudaram equivale a dizer que o próprio desenho dos mesmos tipos se alterou, na evolução verificada desde a LCT de 1969 até ao Código do Trabalho de 2009.

Supomos que ninguém sustenta hoje que tal modificação tenha ocorrido. Recordemos o que se passou neste domínio.

Partindo da definição do contrato de trabalho constante do art. $1^{\circ}$ da LCT de 1969, ocorreram, com a codificação de 2003, duas alterações: a eliminação

4 Razão pela qual, em conformidade com a jurisprudência assente no STJ, se teria aplicado "apenas" a Lei do Contrato de Trabalho aprovada pelo DL 49408, de 24/11/1969. 
da dicotomia "actividade intelectual ou manual", elemento inteiramente supérfluo e carente de alcance diferenciador, e a previsão da pluralidade de empregadores (“a outra ou outras pessoas"), que não é, manifestamente, um factor distintivo do tipo contratual.

O Código de 2009 acrescentou duas outras "novidades" que, na realidade, o não eram de todo: a precisão de que o trabalhador seria sempre uma "pessoa singular" (coisa nunca exposta a dúvidas) e a substituição da referência à "direcção" da actividade pelo empregador pela alusão ao "âmbito de organização" deste ${ }^{5}$, com isso se imprimindo na definição legal uma imagem mais focada da realidade actual das relações de trabalho, sem qualquer amplificação ou redução do tamanho e dos contornos dessa imagem. O tipo negocial a que se conexiona a aplicabilidade das normas de Direito do Trabalho é exactamente o mesmo desde a lei de 1969, em todas as caracteristicas essenciais, cuja detecção nas situações da vida permite a qualificação como contrato de trabalho e a resolução das questões concretas de direito com base naquelas normas. Por outras palavras, carece inteiramente de verdade a afirmação de que os "critérios para a distinção entre contrato de trabalho e contrato de prestação de serviço" sofreram qualquer alteração com a evolução legislativa subsequente à LCT de 1969.

\section{Ainda a Questão da APLiCaÇão no tempo}

A jurisprudência consolidada a que se refere o acórdão acima mencionado assenta, porém, em regra, num discurso que não enfatiza demasiado o argumento da modificação dos "critérios de distinção". Procura, sobretudo, apoio em certa interpretação das normas de direito transitório constantes das leis preambulares das duas versões do Código do Trabalho. Vale a pena revisitá-las brevemente.

O art. 8\%/ da L. 99/2003, de 27 de Agosto, dispunha o seguinte:

"Sem prejuízo do disposto nos artigos seguintes, ficam sujeitos ao regime do Código do Trabalho os contratos de trabalho e os instrumentos de

5 Sobre o ponto, vejam-se as lúcidas ponderações de Maria do Rosário Ramalho, Tratado de Direito do Trabalho, Parte II - Situaçôes laborais individuais, (4a ed., Coimbra, 2012), 37 e ss. 
regulamentação colectiva de trabalho celebrados ou aprovados antes da sua entrada em vigor, salvo quanto às condições de validade e aos efeitos de factos ou situações totalmente passadas anteriormente àquele momento."

Por sua vez, o art. 7\%/1 da L. 7/2009, de 12 de Fevereiro, estabeleceu a seguinte regra de aplicação do Código no tempo:

"Sem prejuízo do disposto no presente artigo e nos seguintes, ficam sujeitos ao regime do Código do Trabalho aprovado pela presente lei os contratos de trabalho e os instrumentos de regulamentação colectiva de trabalho celebrados ou adoptados antes da entrada em vigor da referida lei, salvo quanto a condições de validade e a efeitos de factos ou situações totalmente passados anteriormente àquele momento."

Realçamos de propósito a expressão final de qualquer dos preceitos, pois nela se baseia, pelo menos desde 2007, o raciocínio decisório de suporte à exclusão da presunção quando se trata de litígios emergentes de contratos anteriores à sua consagração em qualquer das fórmulas. No acórdão em que, segundo cremos, primeiramente foi sustentada a doutrina que veio a "consolidar-se" ${ }^{16}$ relatado, aliás, por um dos mais distintos juristas que já passaram pela Secção Social do STJ - e que tinha por objecto um litígio emergente de um contrato celebrado em 1992 - , esse raciocínio exprimiu-se de modo lapidar: "O artigo 12..$^{\circ}$ do Código do Trabalho estabelece a presunção de que as partes celebraram um contrato de trabalho assente no preenchimento cumulativo de cinco requisitos, o que traduz uma valoração dos factos que importam o reconhecimento dessa presunção; por conseguinte, só se aplica aos factos novos, às relações jurídicas constituídas após o início da sua vigência, que ocorreu em 1 de Dezembro de 2003."

Assim, o Supremo considerou que a regra instituidora da presunção de laboralidade, na versão posta em vigor pelo Código de 2003, definia, naturalmente em termos inovatórios, os efeitos de factos totalmente passados. E que factos passados seriam estes? Só podiam ser os factos invocados e provados como suportes da presunção. Repare-se, com efeito, que o "facto" da celebração do contrato, nas condições de tempo, espaço e conteúdo que contextualizaram as estipulações, não estava aí em causa. O que atraiu a atenção do alto Tribunal foi a circunstância de a presunção eleger como seus pilares certos

6 STJ 02/05/2007 - Po 06S4368 (Pinto Hespanhol). 
factos, conferindo-lhes - se provados - um determinado "efeito útil", capaz de influenciar o destino da lide: o de transferir para o empregador o encargo da prova decisiva.

\section{As EXCEPÇÕES À REGRA}

Todavia, esse "efeito útil" não pode, a nosso ver, confundir-se com a "valoração" a que alude a jurisprudência do STJ. Tal "valoração" pretenderia assumir, no contexto da mesma corrente decisória, sentido correspondente à expressão-chave com que o legislador quis, em qualquer das disposições transitórias acima transcritas, designar o "núcleo protegido" face à aplicação imediata de qualquer dos Códigos: "condições de validade e efeitos de factos ou situações totalmente passados" antes da entrada em vigor da lei codificadora. Mas tal correspondência não tem um mínimo de fundamento. Tomemos um exemplo. As normas que regulam a presunção de laboralidade elegem como possível fundamento da mesma, entre outros, o facto de o trabalho ser normalmente executado em instalação do empregador. Dizer que este é um facto "totalmente passado" é negar a evidência. E só disso pode tratar-se. $\mathrm{Na}$ verdade, o facto da celebração do contrato (independentemente da sua qualificação) - facto esse que a jurisprudência consolidada toma como momento decisivo para a aplicação das referidas normas transitórias - não está no regime que estrutura a presunção, não lhe pertence. Não é a esse facto que se liga a presunção e o seu típico efeito de inversão do ónus da prova da natureza do vínculo.

E bem se entende que tal facto - o da celebração do contrato - seja tendencialmente neutro para o processo de qualificação e de escolha da lei aplicável à situação concreta. Tratando-se de uma relação duradoura, a factualidade por que ela se manifesta vai sofrendo alterações mais ou menos subtis, que podem envolver (ou não) mudanças de qualificação ${ }^{7}$.

7 Essa possibilidade foi, recentemente, ilustrada pelo Supremo. Veja-se STJ 15/05/2019 — Po 2759/17.7T8BRR.L1.S1 (Júlıo Gomes). Aí se tratou de um contrato de trabalho originário que "derivou" para prestação de serviço, em consequência do facto de o trabalhador ter contratado outra pessoa para com ele partilhar as actividades a que se obrigara. 
Quando um litígio emergente de um contrato com essas características é levado a tribunal, o que se pretende é que a respectiva qualificação assente na realidade actual ${ }^{8}$ - ou passada, mas localizada em certa fase do desenvolvimento daquela factualidade - e não, propriamente, no perfil do contrato tal como as estipulações iniciais das partes o desenharam?

Assim, e em primeiro lugar, parece, desde logo, fora de causa que na construção da presunção de laboralidade se trate de conformar "condições de validade" do contrato de trabalho. A questão levanta-se apenas acerca dos "efeitos de factos ou situações totalmente passados" - efeitos jurídicos, decerto, e não simplesmente consequências práticas nem inferências lógicas que se possa extrair de tais factos. Ora os factos em jogo só podem ser, como atrás se disse, os que, nos termos da lei, suportam a presunção, e os "efeitos" que deles podem decorrer através da dinâmica da presunção são de natureza meramente lógica e instrumental para a qualificação do contrato, não envolvendo nenhuma especial "valoração" sob o ponto de vista jurídico. De resto, nem se tratará de "factos ou situações passados”, dado que a qualificação atenderá, fundamentalmente, às características da situação actual (relativamente ao quadro litigioso) em que se encontrem as relações de trabalho - ou seja, a factos ou situações actuais hoc sensu.

Arredadas assim, a nosso ver, as excepções à regra previstas no art. $7^{\circ} \mathrm{da}$ L. 7/2009, resta a regra: aplica-se o art. 12 do Código do Trabalho de 2009 aos contratos de trabalho celebrados antes da entrada em vigor do mesmo Código.

8 Pronunciava-se nesse sentido, por exemplo, Rel. Lisboa 02/11/2015 - P. 4113/10.2TTLSB.L1-4 (Alda Martins).

9 Veja-se, sobre tudo isto, a crítica semelhante de Milena Rouxinol, Notas sobre a eficácia temporal do artigo $12^{\circ}$ do Código do Trabalho - A propósito do Acórdão do Tribunal da Relação do Porto de 7 de Outubro de 2013, (ULP LAW REVIEW- Revista de Direito da ULP, vol. 4, no 4, 2014), 70-83. Pode ver-se também o nosso comentário Uma jurisprudência consolidada: a presunção de laboralidade, em Minerva-Revista de estudos laborais, (ano IX, $\mathrm{n}^{\circ}$ 1, 2019), 225-248. Deve assinalar-se que, na doutrina - especialmente na manualística —, o problema ou é omitido, ou é abordado em perspectiva crítica idêntica a que aqui se expõe. É o caso do manual de João Leal Amado, Milena Silva Rouxinol, Joana Nunes Vicente, Catarina Gomes Santos e Teresa Coelho Moreira, Direito do Trabalho. Relação individual, (Coimbra, 2019), 94 e ss. 


\section{O MÉTODO TIPOLÓGICO}

Em reforço deste entendimento, deve reconhecer-se que o próprio método tipológico ou indiciário que os tribunais utilizam é, por definição, dirigido à realidade ("actual", no sentido referido acima) dos factos por que se desentranha a relação laboral, atribuindo um significado muito limitado ao momento da celebração do contrato e à qualificação que as partes lhe atribuíram. Com suporte na análise da situação real em que se encontra a relação discutida, os tribunais destacam certos elementos de facto que lhes permitem atingir uma conclusão aproximativa acerca da natureza da mesma relação. A qualificação é, assim feita, com base em factos mais ou menos distantes, no tempo, da celebração do contrato, sendo a "valoração desses factos" o resultado de um balanceamento determinado por critérios que os contraentes não podiam sequer prever.

Deste modo, o método tipológico conduz à realização de uma operação qualificativa - ainda que por "aproximação" - cujo objecto, como não podia deixar de ser, consiste nos desenvolvimentos reais e actuais que as relações entre as partes manifestam.

É esse, aliás, também o objecto relevante para a decisão que deva ser tomada sobre o fundo do litígio. A démarche qualificativa do tribunal não incide sobre aquilo que os contraentes quiseram ou disseram querer, nas estipulações iniciais ${ }^{10}$, mas sobre aquilo que se apresenta aos olhos do julgador como realidade "actual" (referida ao tempo das situações litigiosas) da relação

10 Até por isso, não parece sufragável a tendência decisória que se afirmou, por exemplo, em STJ 21/09/2017 - P. 2011/13.7TTLSB.L2.S1 (Ferreira Pinto): “O 'nomen juris' que as partes deram ao contrato (Contrato de Avença) e o facto das cláusulas nele inseridas se harmonizarem com o contrato de prestação de serviço, não sendo decisivos para a qualificação do contrato, não deixam de assumir especial relevo, uma vez que a vontade negocial assim expressa no documento não poderá deixar de assumir relevância decisiva na qualificação do contrato, salvo nos casos em que a matéria de facto provada permita concluir, com razoável certeza, que outra foi realmente a vontade negocial que esteve subjacente à execução do contrato." Duas razões apontam para que se não atribua ao nome dado ao contrato nas estipulações iniciais mais do que uma relevância absolutamente marginal, ou mesmo nenhuma. A primeira deriva de tudo o que se sabe acerca da panóplia de manobras simulatórias existente neste domínio, uma das quais incide justamente na formulação do contrato (nome e clausulado). A segunda, decisiva, resulta do que se explica no texto: a qualificação de um contrato de execução duradoura, como é o contrato de trabalho, só pode fundar-se em juízos de realidade, sobre o modo por que em concreto se desenvolvem as relações entre as partes, porventura de modo evolutivo e até com cambiantes de natureza jurídica. 
controvertida - independentemente da data mais ou menos recuada em que o contrato tenha sido celebrado.

Os elementos de que o tribunal se serve para aplicar o referido método variam de caso para caso; há, decerto, uma "lista de índices" que se vai consolidando, mas o modo por que, em cada decisão, são escolhidos e valorizados os índices de subordinação/autonomia depende do critério do julgador. E, de qualquer modo, o resultado dessa operação é uma decisão acerca da qualificação do contrato (do longínquo contrato...) segundo a fisionomia actual das relações entre as partes ${ }^{11}$.

\section{A FUnÇão da presunÇão}

\section{Ora a presunção de laboralidade não vai tão longe. A prova dos factos que} lhe servem de base não assume natureza conclusiva nem habilita, sem mais, $o$ tribunal a definir a lei aplicável à situação litigiosa ${ }^{12}$. Os elementos compen-

11 Merece ser assinalado, por várias razões, RG 14/05/2015 - P. 995/12.1TTVCT.G1 (ANTERo VEIGA). Assumindo sem rebuço uma linha discordante com a jurisprudência assente do STJ, sustentou, com argumentação extensa e consistente, que "é de aplicar o artigo $12 .{ }^{\circ}$ do CT aos contratos subsistentes aquando da sua entrada em vigor". Porém, no desenvolvimento do raciocínio decisório, acabou por, praticamente, secundarizar o mecanismo da presunção. Com efeito, e em primeiro lugar, desenrolou pormenorizada aplicação do método tipológico, índice por índice, com expressão na súmula ("Na delimitação entre o contrato de trabalho e o contrato de prestação de serviços deve-se recorrer a factos/índice dos quais se possa concluir pela existência de um contrato de trabalho" e "Os índices devem ser apreciados no seu todo, sopesando o peso relativo de cada um e o seu número, o modo como se articulam em concreto, surpreendendo o que é marcante na relação, independentemente de uma aparência artificialmente criada"). Depois, considerou susceptível de neutralizar a presunção uma nebulosa demonstração da vontade real das partes: "Tudo o referido está condicionado pela livre vontade das partes. Tratando-se de negócios da natureza consensual, não pode deixar de se atender e relevar a vontade real das partes, traduzida não apenas na qualificação que lhe deram, mas sobretudo nos termos em que definiram as condições do exercício da atividade, nos termos acordados. Isto, desde que se possa concluir com razoável segurança que a vontade do prestador, parte mais fraca da relação, se determinou de forma livre, e a configuração e desenvolvimento da relação não for de todo espúria ao contrato celebrado." Esta consideração levou a que a decisão, ladeando a prova feita de alguns dos factos apoiantes da presunção, se voltasse para o reconhecimento, sem mais, da existência de um contrato de prestação de serviço. A situação concreta era a seguinte: os dois contraentes tiveram, durante algum tempo, um contrato de trabalho; a certo passo, e mediante uma compensação económica ao trabalhador, foi celebrado entre os dois um denominado contrato de prestação de serviço, exactamente com o mesmo objecto e para ser executado nos mesmos termos...

12 Note-se que o modelo de presunção de laboralidade consagrado no Estatuto de los Trabajadores espanhol - com o qual a formulação do art. $12^{\circ}$ do Código português tem inegável parentesco assume, aos olhos da jurisprudência pertinente, dupla função. Como evidencia a sua inserção no art. $8 / 1$ do Estatuto, respeitante à forma do contrato de trabalho, a presunção começa por servir 
diados no art. $12^{\circ}$ não têm a função de verdadeiros índices de subordinação — não são, nesse sentido, "a mesma coisa" que a matéria indiciária utilizada no método tipológico. Nenhuma conclusão se extrai da verificação de um ou mais desses elementos na situação concreta. A invocação da presunção só pode servir para regular o encargo da prova relativamente à natureza da relação contratual controvertida ${ }^{13}$. Demonstrados factos suficientes para que ela funcione, a consequência consiste em que o empregador passa a ter o ónus da prova do contrário ${ }^{14}$ - em suma, da prova da existência de um contrato de prestação de serviço.

Existem, na jurisprudência consolidada, indicações no sentido de que se instalou no STJ uma convicção muito diferente acerca do funcionamento da presunção de laboralidade. Lê-se, por exemplo, num acórdão bastante recente ${ }^{15}$, o seguinte: "ao contrário do modelo indiciário, que apelava a uma ponderação global dos elementos caracterizadores da concreta relação estabelecida entre partes, destacando nos mesmos aqueles que apontam para a subordinação jurídica, a sopesar com os que apontam no sentido da autonomia, de forma a encontrar o sentido global caracterizador da relação, $a$ demonstração da existência de contrato de trabalho vai ficar agora dependente, e apenas, da demonstração do conjunto dos indices consagrados nas alíneas do $n^{\circ}$ 1 do artigo $12^{\circ}$ " (itálico nosso).

Este trecho pertence à fundamentação de uma decisão, proferida em 2019, com base na versão do art. 12 constante do Código de... 2003 - naturalmente, por aplicação da doutrina adoptada pelo Supremo em matéria de aplicação dessa norma no tempo. O facto de, nessa versão, a presunção de laboralidade assentar na verificação cumulativa de cinco aspectos da relação que, qualquer deles, isoladamente, permitiria inferir a

para determinar a existência do próprio contrato, em situações em que o consenso das partes não se traduz em declarações expressas; depois, pode ser usada também, como presunção iuris tantum, para a respectiva qualificação. Cfr. Antonio Martin Valverde, Fermín Rodriguez-Sañudo Gutierrez, Joaquín García Múrcia, Derecho del Trabajo, (25a ed., Madrid, 2016), 521-522.

13 Esta função é lapidarmente explicada, por exemplo, em RL 13/01/2016 - P. 349/14.5TTLRS. L1-4 (José Eduardo Sapateiro).

14 Cfr. RP 14/12/2017 - P. 1694/16.0T8VlG.P1 (Paula Leal de Carvalho).

15 STJ 10/09/2019 - P. 1358/16.5T8CSC.L2.S1 (ANTÓnio LeONES DANTAS). Voltaremos a encontrá-lo mais adiante. 
existência de contrato de trabalho, torna inteligível, ainda que não plausível, o raciocínio expresso no texto transcrito. $\mathrm{Na}$ verdade, "esse" art. $12^{\circ}$ não consagrava uma presunção, mas uma certeza absoluta. Sendo a prova dos factos enumerados encargo do trabalhador, podia dizer-se que havia aí mais uma especificação da regra do ónus da prova constante do art. 342\% 1 do Código Civil do que, propriamente, uma presunção legal susceptível de provocar a redistribuição desse ónus. O legislador teria querido explicitar o que deveria o trabalhador provar para que se considerasse existir um contrato de trabalho.

Mas o trecho transcrito, tal como a restante fundamentação do acórdão quanto a esta matéria - de acordo, aliás, com o texto da lei a que se reporta -, continua a falar de "presunção" e, inclusivamente, do mecanismo de inversão do ónus. E aqui parece necessário sublinhar que, tratando-se de uma presunção ilidível, cujo preenchimento só transfere para o empregador o encargo de provar a existência de um contrato de prestação de serviço, não parece exacto dizer-se, mesmo em presença da versão de 2003 - como um pouco adiante se lê na fundamentação do mesmo acórdão - que "a lei faz decorrer do conjunto dos factos descritos nas alíneas deste artigo $12^{\circ}$ que caracterizam a relação entre o prestador e o seu beneficiário, um efeito jurídico específico - a existência de contrato de trabalho, ou seja, de uma relação de trabalho subordinado entre as partes envolvidas naquela prestação de actividade".

\section{A RESPONSABILIDADE DO LEGISLADOR}

Note-se que o próprio legislador não estará isento de responsabilidade quanto à criação de percepções menos exactas sobre a função da presunção de laboralidade. Referimo-nos ao que dispõe o art. $15^{\circ}-\mathrm{A}^{16}$ da L. 107/2009, de 14 de Setembro, a propósito da actuação do inspector do trabalho face a situações de aparente dissimulação do contrato de trabalho. Na sua primeira versão (a da L. 63/2013), o n ${ }^{\circ} 1$ desse artigo desenhava a hipótese de o inspector verificar "a existência de indícios de uma situação de prestação de

16 Introduzido pela L. 63/2013, de 27 de Agosto, e alterado pela L. 55/2017, de 17 de Julho. 
atividade, aparentemente autónoma, em condições análogas ao contrato de trabalho, nos termos descritos no artigo $12 .^{\circ}$ do Código do Trabalho, aprovado pela Lei n. ${ }^{\circ}$ 7/2009, de 12 de fevereiro". Na versão revista (pela L. 55/2017), a hipótese é descrita noutros termos, mas com base na mesma ideia. É o caso de o inspector verificar "na relação entre a pessoa que presta uma atividade e outra ou outras que dela beneficiam, a existência de características de contrato de trabalho, nos termos previstos no $n .^{\circ} 1$ do artigo $12 .{ }^{\circ}$ do Código do Trabalho, aprovado pela Lei n. ${ }^{\circ} 7 / 2009$, de 12 de fevereiro”. A partir de qualquer dessas hipóteses, a lei estabelece que o inspector "lavra um auto e notifica o empregador para, no prazo de 10 dias, regularizar a situação, ou se pronunciar dizendo o que tiver por conveniente". Com esta actuação, o inspector desencadeia um procedimento que, no caso de o empregador não contemporizar com o que lhe é exigido, desembocará em tribunal, sob o impulso do Ministério Público, nos termos dos arts. $186^{\circ}-\mathrm{K}$ e seguintes do Código do Processo do Trabalho.

Esse procedimento incorpora um contraditório apenas aparente, pois dos restantes números do mesmo art. $15^{\circ}$-A resulta que, lavrado o auto e feita a notificação, só se abrem duas possibilidades: ou o empregador regulariza a situação, no sentido pretendido pelo inspector, ou a questão é remetida ao Ministério Público para que seja instaurada a acção de reconhecimento da existência de contrato de trabalho. A "defesa” do empregador, aparentemente, de pouco ou nada serve.

Isto significa que a qualificação feita, em fase administrativa, pelo inspector do trabalho, e de que são retiradas consequências imediatas, assenta, por indicação da própria lei, na verificação de dados de facto que, na perspectiva do art. $12^{\circ}$ do Código do Trabalho, apenas legitimam uma presunção iuris tantum.

$\mathrm{Na}$ realidade, segundo cremos, a referência a essa disposição legal é errada e inoportuna. Sobretudo na versão melhorada de 2017, o art.15-A/1, a expressão qualificante - "na relação entre a pessoa que presta uma atividade e outra ou outras que dela beneficiam, a existência de características de contrato de trabalho" - é suficiente para orientar a apreciação da situação concreta pelo inspector, sem necessidade de aproximar essa apreciação de qualquer presunção legal. As características do contrato de trabalho e os 
índices de subordinação jurídica são conhecidos, estão "tabelados”, têm como suporte uma jurisprudência robusta. $\mathrm{O}$ inspector do trabalho não joga com nenhuma presunção - forma uma convicção e actua com base nela, embora com resultados sujeitos a escrutínio judicial.

A referência ao art. $12^{\circ}$ do Código do Trabalho restringe ou condiciona o critério de apreciação do inspector e sugere uma aplicação da presunção de laboralidade que, realmente, não corresponde à perspectiva da sua criação na lei.

\section{A eVoluÇão do Pensamento legislativo}

Essa perspectiva só adquiriu verdadeira consistência com o Código do Trabalho de 2009. Antes, como se sabe - e não vamos recordar detalhadamente aqui - existiu, no Código de 2003, uma lastimosa caricatura de presunção de laboralidade (que nem por isso deixou de ser compenetradamente invocada em certas decisões judiciais ${ }^{17}$ ), e, um pouco mais $\operatorname{tarde}^{18}$, uma formulação com o seu quê de seriedade, mas ainda funcionalmente inepta ${ }^{19}$.

Entre as duas codificações, a vontade do legislador modificou-se claramente.

Em 2003, a presunção apareceu consagrada num artigo solto, e com uma formulação que sugeria ter-se tratado de uma "concessão" negocial feita a contragosto no quadro da concertação social. $\mathrm{Na}$ exposição de motivos da proposta de lei 29/XI, que viria a resultar nesse Código, não havia uma palavra sobre o assunto, o que não deixa de surpreender, uma vez que a presunção de laboralidade (ainda que esvaziada de qualquer utilidade) constituía uma novidade absoluta no nosso ordenamento. $O$ facto de, na formulação então consagrada, ser exigida a prova cumulativa de vários

17 Muito recentes, aliás: veja-se, por exemplo, STJ 01/09/2019 - P. 1376/16.3T8CSC.Li.S1 (Ribeiro Cardoso).

18 Com a Lei no 9/2006, de 20 de Março.

19 Sobre o tema, pode ver-se o nosso Direito do Trabalho, (20a ed., Coimbra, 2020), 166 e ss., e Maria do Rosário Ramalho, Tratado de Direito do Trabalho, Parte II - Situaçôes laborais individuais cit., 47 e ss. 
aspectos da relação de trabalho, de que, porém, bastaria um só para se formar, não uma presunção, mas a certeza da existência de um contrato de trabalho, é, a nosso ver, suficiente para se inferir que a presunção não era, realmente, desejada pelo legislador histórico, e que foi incluída na codificação como um corpo estranho, votado à inconsequência - como atrás se procurou mostrar.

No Código de 2009, a presunção da existência de contrato de trabalho surge num art. $12^{\circ}$ reformulado, que claramente se orienta para o combate à simulação laboral. Era conhecido o progressivo agravamento da situação em Portugal, e não só em Portugal. A OIT emanara em 2006 a Recomendação $\mathrm{n}^{\circ} 198$, que preconizava "a luta contra as relações de trabalho encobertas" e indicava aos Estados a necessidade de adoptarem medidas concretas com esse objectivo. Entre as medidas sugeridas contava-se, justamente, a consagração de "uma presunção legal da existência de uma relação de trabalho quando se verificam um ou vários indícios” ${ }^{20}$. A reconfiguração do art. $12^{\circ}$ e o novo perfil dado à presunção de laboralidade não podem ser desligados desse contexto ${ }^{21}$. A presunção foi acoplada a um regime sancionatório severo, aplicável às situações em que se verifique "a prestação de actividade, por forma aparentemente autónoma, em condições características do contrato de trabalho" (nos 2 a 4). Este regime viria a ser desenvolvido e ampliado pela L. 63/2013, de 27 de Agosto, ao introduzir o art. 15-A da L. 107/2009 e os arts. $186^{\circ}-\mathrm{K}$ a $186^{\circ}-S$ do Código do Processo do Trabalho. A presunção foi aí englobada num grupo de medidas destinadas a atacar o actualíssimo e

20 A Recomendação foi ao ponto de, para além da presunção, definir o conjunto dos indícios de que deveria retirar-se a conclusão da existência de um contrato de trabalho: (a) o facto de que o trabalho: se realiza segundo as instruções e sob o controlo de outra pessoa; que o mesmo implica a integração do trabalhador na organização da empresa; que é efectuado única ou principalmente em benefício de outra pessoa; que deve ser executado pessoalmente pelo trabalhador, dentro de um horário determinado, ou no lugar indicado ou aceite por quem solicita o trabalho; que o trabalho é de certa duração ou tem continuidade, ou requer a disponibilidade do trabalhador; que implica o fornecimento de ferramentas, materiais e maquinarias por parte da pessoa que recebe o trabalho, e (b) o facto de que é paga uma remuneração periódica ao trabalhador; de que essa remuneração constitui a única ou a principal fonte de rendimento do trabalhador; de que inclui pagamentos em espécie, como alimentação, habitação, transporte ou outros; de que se reconhecem direitos como o descanso semanal e as férias anuais; de que a parte que recebe o trabalho paga as viagens que há-de fazer o trabalhador para executar o seu serviço; o facto de que não existem riscos financeiros para o trabalhador.

21 Esse enquadramento da presunção desenhada em 2009 foi devidamente assinalado pelo Supremo, embora sem reflexos na "jurisprudência consolidada" sobre a sua aplicação. Veja-se, por exemplo, STJ 11/11/2020 - P. 2609/19.0T8OAZ.P1.S1 (José Feteira). 
gravíssimo problema da sistemática dissimulação, pelos mais diversos expedientes, da existência de trabalho subordinado... onde ele realmente existe. $\mathrm{O}$ art. $12^{\circ}$ passou, assim, a constituir a expressão de um "activismo" legislativo tendente a provocar um "virar de página" na situação de persistente inefectividade das normas laborais, decorrente do não reconhecimento da chave de acesso que é o contrato de trabalho ${ }^{22}$.

Esse "activismo" não envolveu, contudo, nenhum radicalismo. Lá, onde a subordinação não exista, a lei do trabalho não tem espaço para se aplicar directamente. Mas, desde logo, e mesmo prescindindo da funcionalidade ligada a uma "causa" que o legislador assumiu como sua, parece inegável que a presunção encontra razões de legitimidade no facto de o trabalho subordinado constituir a modalidade normal e amplamente maioritária do trabalho em proveito de outrem. As presunções vivem de normalidades, não são construções inteiramente artificiais de que o legislador se sirva para transfigurar a realidade.

Por outro lado, a demonstração das bases da presunção não leva - vale sempre repeti-lo - a qualquer conclusão qualificante, sobre a qual se possa fazer assentar a escolha da lei do trabalho para tratar a situação concreta. Essa demonstração, a cargo do trabalhador, coloca simplesmente o empregador na posição, de certo modo natural, de provar factos que consubstanciem a existência, na mesma situação, de um modelo de relação de trabalho que é, no "mercado dos serviços individuais em proveito alheio", de verificação muito menos frequente do que o modelo contraposto.

De qualquer modo, o mencionado rasgo de "activismo" legislativo, apontado ao combate à simulação laboral, explicava-se pelas proporções que a dissimulação do contrato de trabalho tinha atingido e que contribuíam fortemente para que, em grande parte, as medidas de protecção dos trabalhadores como contraentes débeis caíssem no vazio. $\mathrm{O}$ art. $12^{\circ}$ do Código de 2009 - muito diferentemente do que podia dizer-se acerca do mesmo artigo no Código de 2003 - incorporava, pois, uma política legislativa de actuação sobre a realidade coetânea. A vontade do legislador passava a ser,

22 Salientando esta "intenção político-legislativa”, veja-se também João Leal Amado, Milena Silva Rouxinol, Joana Nunes Vicente, Catarina Gomes Santos, Teresa Coelho Moreira, Direito do Trabalho cit., 94 e ss. 
sem margem para dúvidas, a de atacar de modo incisivo uma realidade que era dissolvente para o próprio ordenamento jurídico-laboral.

\section{UMA QUESTÃO (TAMBÉM) DE INTERPRETAÇÃo}

A jurisprudência consolidada do STA sobre a matéria deve, também, ser apreciada à luz desse propósito legislativo.

Com todo o respeito, julgamos necessário assinalar que o problema não é apenas de aplicação da lei no tempo - envolve uma questão de interpretação da lei, que é a da evidenciação do seu sentido profundo, correspondente ao desígnio legislativo subjacente. Essa jurisprudência assenta, pois, numa certa interpretação do art. $12^{\circ}$ do Código do Trabalho, uma interpretação que lhe atribui uma "funcionalidade neutra" relativamente à aplicação do regime do contrato de trabalho, como mero instrumento de gestão do processo de identificação desse contrato nas situações reais controvertidas - como era ou pretendia ser a versão do mesmo artigo no Código de 2003. Mas isso significa ignorar de todo a evolução verificada no domínio da política legislativa, isto é, do pensamento e do desígnio do legislador, desde 2003 a 2009.

Deste modo, a interpretação adoptada na jurisprudência do STJ prescinde de elementos recomendados pelo art. $9^{\circ}$ do Código Civil, como "as circunstâncias em que a lei foi elaborada e as condições específicas do tempo em que é aplicada". O atendimento destas "circunstâncias" e "condições" levaria, decerto, a reconhecer que a nova redacção do art. $12^{\circ}$, introduzida com a codificação de 2009, visava atacar uma realidade sentida na própria época em que essa reforma legislativa foi posta em vigor, de acordo com o critério de premência que os problemas suscitados por essa realidade impunham.

E não se pense que essa inconsideração de corolários naturais da reformulação do art. $12^{\circ}$ foi inconsequente sob o ponto de vista do cumprimento da lei. A presunção de laboralidade nem sempre é chamada à colação ${ }^{23}$, quando

23 E, no entanto, a activação da presunção não é facultativa nem depende de alegação das partes, é "de preceito". A partir do momento que a prova produzida permite considerar verificados factos susceptíveis de preencherem alíneas do art. 12\%1, o "uso" da presunção é manifestamente forçoso. 
se trata de qualificar relações de trabalho. Nos casos em que a possibilidade é ventilada, o saldo líquido traduz-se, praticamente, na neutralização do mecanismo. Vale a pena recordar alguns dos recentes acórdãos do STJ em que, de um modo ou de outro, veio a propósito.

\section{Primeiro caso: um tradutor de legendas}

Numa decisão de $2018^{24}$, apreciou-se a situação de um tradutor que estava ao serviço de uma estação de televisão desde data anterior a 1 de Julho de 2002 até ao presente (2017, ano em que a Autoridade para as Condições de Trabalho tinha tido intervenção e fora instaurada acção de reconhecimento da existência de contrato de trabalho). A relação de trabalho (fosse qual fosse a sua correcta qualificação) tinha sido, ao longo desse dilatado período, titulada por sucessivos contratos escritos (em 2010, 2013 e 2014), todos denominados "contratos de prestação de serviço", e com sucessivos aditamentos.

Da matéria de facto fixada nas instâncias, permitimo-nos destacar (por nossa conta e risco), como elementos mais significativos, os seguintes ${ }^{25}$ : o Autor foi contratado para exercer as funções de tradutor, que compreendiam a tradução para legendagem para língua portuguesa de peças jornalísticas e/ou informativas da área da informação diária e não diária, no âmbito da Direção de Informação da Ré, qualquer que fosse a notícia, relato, acontecimento ou evento, rubrica ou serviço de programas (canal) a que se destinassem, nomeadamente informação política, social, económica, cultural ou desportiva; o serviço feito pelo Autor foi sempre prestado nas instalações pertencentes à Ré, com utilização dos equipamentos e instrumentos de trabalho da Ré, nomeadamente: secretária, cadeira, computadores (legendadores), televisão, etc., usando software específico para a realização das suas tarefas disponibilizado pela Ré, como seja o "poliscript"; os tradutores que integravam a equipa de traduções e prestavam a sua atividade à Ré exerciam funções em turnos pré-definidos por esta, durante sete dias por

24 STJ 27/11/2018 - P. 14910/17.2T8SNT.L1.S1 (ANTónio Leones Dantas).

25 O enunciado que se segue foi transposto, com ajustamentos gramaticais mínimos, do quadro de matéria de facto provada constante do próprio acórdão. 
semana, entre as $05 \mathrm{~h} 00$ e $24 \mathrm{~h} 00$ durante os dias de semana e entre as $07 \mathrm{~h} 00$ e as $24 \mathrm{~h} 00$ durante os fins-de semana; durante o referido horário, o trabalho era exercido em turnos organizados em função das necessidades de trabalho dos serviços de informação, nos termos definidos pela Ré; a Direção de Informação comunicava à equipa de tradutores o número de tradutores que deviam estar presentes nas instalações da Ré durante certos horários específicos, nomeadamente durante os horários com maior número de programas noticiosos; para assegurar a prestação dos serviços relativamente à informação, a equipa de tradução organizava-se entre si, sem qualquer intervenção da Ré, de modo a assegurar a presença de um tradutor nas instalações desta que corresponda à urgência do serviço que lhes é comunicado; a Ré somente pretendia que as traduções e legendagens fossem apresentadas a tempo e de modo a serem incorporadas nos serviços noticiosos da estação, independentemente da identidade do prestador; a equipa de tradutores recebia, por e-mail, indicações, instruções e comunicações quanto ao horário e ao número de tradutores que deviam estar presentes nas instalações da Ré; as prioridades dos trabalhos a concluir eram definidas pela Ré, que comunicava e instruía a equipa de tradutores sobre que trabalhos eram prioritários e as horas a que os mesmos deveriam estar concluídos; a equipa de tradutores recebia por parte da Ré indicações editoriais e funcionais; a equipa de tradutores contactava diretamente com os jornalistas da Ré, que pediam diretamente ao tradutor que se encontrasse presente a tradução e legendagem de peças informativas; quando necessitava de se ausentar, ou de gozar períodos de descanso, o Autor tinha que o comunicar verbalmente ou por escrito (email) aos demais elementos que integravam a equipa de tradutores, para garantir a respetiva substituição por pessoa que assegurasse a realização do mesmo serviço no horário que lhe estava previamente atribuído, dando ainda conhecimento de tais ausências à Ré por uma questão de cortesia; tais ausências não eram descontadas no valor mensal que recebia por parte da Ré, nem dependiam de prévia autorização da Ré; quando o Autor exercia as suas funções fora do horário supra referido, era-lhe paga pela Ré uma contrapartida pecuniária extraordinária; desde o início e de forma ininterrupta, o Autor recebia, como contrapartida pela atividade prestada, uma compensação 
pecuniária definida pela Ré e que integrava uma componente fixa e certa, quanto às funções de tradução para legendagem para língua portuguesa de peças jornalísticas e/ou informativas da área da informação diária e não diária, no âmbito da Direção de Informação da Ré, e por uma componente variável, relativamente aos programas fora do âmbito da informação (nomeadamente filmes, séries e documentários), paga em função do volume e quantidade de trabalho e mediante valores definidos, aprovados e em vigor na RTP; sobre os valores que auferia, o Autor emitia recibos, seguindo o regime específico dos rendimentos do trabalho autónomo ou independente; a Ré não impunha ao Autor um regime de exclusividade, podendo o mesmo prestar a sua atividade a terceiros, sem comunicação ou autorização prévia da Ré, como efetivamente fez nos anos de 2014, 2015 e 2016; o Autor nunca recebeu subsídios de férias e de Natal.

Não se trata aqui, evidentemente, de discutir a qualificação mais correcta que este conjunto de factos sugere para a relação contratual existente entre o tradutor e a estação de televisão. $\mathrm{O}$ acórdão considerou não existir contrato de trabalho, tal como, de resto, vinha das instâncias, e fundamentou essa decisão com elementos relevantes da matéria de facto provada. O que nos permitimos, com todo o respeito, questionar é o facto de que, inserindo-se as várias decisões numa fase tão adiantada de uma relação contratual duradoura (aliás contratada, manifestamente, como de execução duradoura), e sendo pronunciadas oito anos depois de o legislador ter introduzido no sistema um dispositivo destinado a servir o combate à fraude laboral, tenha sido possível pôr de lado esse dispositivo, apesar de a situação fornecer elementos mais do que suficientes para que ele funcionasse.

\section{SEgundo CASO: UM INSTRUTOR DE GINÁSTICA}

Tomemos em mãos um outro aresto, já de $2019^{26}$. O caso referia-se ao contrato - denominado "contrato de prestação de serviços" - celebrado, em Agosto de 2007, entre o Autor e uma empresa exploradora de um Health Club, segundo o qual: «... o segundo contraente se obriga a prestar à $1 .{ }^{a}$

26 STJ 09/01/2019 - P. 1376/16.3T8CSC.L1.S1 (RIBEIRo CARDOSO). 
Contraente, após prévia solicitação desta, serviços de Instrutor de Ginástica, preferencialmente em regime de Treino Personalizado (personal trainer) $\gg$, bem assim, «... mediante solicitação da $1 .{ }^{\text {a }}$ contraente, realizar trabalhos de pesquisa, preparação e organização de projetos e eventos sobre matérias relacionadas com a sua prestação de serviços». A empresa pôs termo às relações contratuais em Maio de 2015. O Autor pretendia o reconhecimento desse vínculo como contrato de trabalho e, ainda, o pagamento de certos créditos respeitantes a 2015.

O primeiro elemento da resposta do Supremo a essa pretensão referiu-se à aplicação da presunção de existência de contrato de trabalho, de acordo com a jurisprudência consolidada: "Assim, aquando da celebração do contrato estava em vigor o Código do Trabalho de 2003 (doravante apenas CT), com as alterações introduzidas pela Lei 9/2006 de 20/03, sendo este, por isso, o regime aplicável à qualificação jurídica do contrato dado que, de acordo com os factos provados, o contrato se desenvolveu sem alteração até 8 de maio de 2015" (itálico nosso).

Deste modo, o regime presuntivo considerado era - recordemo-lo - do seguinte teor: "Presume-se que existe um contrato de trabalho sempre que o prestador esteja na dependência e inserido na estrutura organizativa do beneficiário da actividade e realize a sua prestação sob as ordens, direcção e fiscalização deste, mediante retribuição."

Tendo presente este pressuposto, acompanhemos os passos conclusivos do raciocínio expresso no acórdão, a partir de elementos da matéria de facto provada:

"Perante a presunção estabelecida no art. $12^{\circ}$ do CT, importa antes de mais averiguar se o A. prestava a sua atividade inserido na estrutura organizativa da R.

(...)

Perante este quadro factual, afigura-se inquestionável que, efetivamente, $o$ A. prestava a sua atividade inserido na estrutura organizativa $d a R$.

Mas serão os factos provados suficientemente indiciadores de que o A. realizava a sua prestação sob as ordens, direcção e fiscalização da Ré?

(...)

Resulta destes factos a existência de alguma subordinação do $A$. à $R$. no exercício das suas funções. 
Mas serão suficientes para permitirem concluir que o A. exercia as funções sob as ordens, direção e fiscalização da $R$ ?

(...)

(...)

Em suma, os factos provados não demonstram que o A. exerceu as funções sob as ordens, direção e fiscalização da Ré, certo como é que, nos termos do art. $342^{\circ}$ do CC, sobre ele impendia o ónus dessa prova, o que basta para afastar a presunção estabelecida no art. $12^{\circ}$ do CT, impondo-se, por consequência, a revogação do acórdão recorrido e a repristinação da sentença da $1^{a}$ instância" (todos os itálicos são nossos) ${ }^{27}$.

De novo se sublinha que não está aqui em causa apreciar criticamente a decisão final quanto à qualificação do contrato. Mas julga-se legítimo assinalar que, perante uma relação contratual desenvolvida entre 2006 e 2015, e num acórdão pronunciado em 2019, a doutrina assente pelo STJ conduziu a que se tivesse deixado de lado o dispositivo idealizado pelo legislador seis anos antes para combater a simulação laboral, preferindo-se-lhe uma fórmula mais antiga, e totalmente inepta, que se traduzia, afinal, como no próprio texto se reconhecia, numa reiteração do disposto no art. $342^{\circ}$ do Código Civil em matéria de atribuição do ónus da prova. Por outras palavras: o resultado foi a neutralização do desígnio legislativo ínsito no art. 12\%/1 do Código do Trabalho de 2009.

\section{TERCEIRO CASO: OUTRO INSTRUTOR DE GINÁSTICA}

Estava também em causa a situação de um instrutor de ginástica, num terceiro case study oferecido por um outro acórdão de $2019^{28}$, referente a uma relação contratual que se estendeu de Julho de 2004 a Junho de 2015, e em que estavam em causa créditos do trabalhador respeitantes a

27 Bem vistas as coisas, a decisão (se bem a entendemos) pode resumir-se deste modo: apesar de se terem provado vários aspectos favoráveis ao reconhecimento da existência de subordinação, o trabalhador não conseguiu fazer prova completa da base da presunção de laboralidade - logo, não há contrato de trabalho. Digamos que, em sentido inverso, a presunção é promovida a chave qualificativa, o que, como se notou várias vezes, não corresponde ao seu papel.

28 STJ 1358/16.5T8CSC.L2.S1 (António Leones Dantas). 
este último ano. A semelhança com o caso anterior permite supor que a empresa envolvida seria a mesma. Também aqui se tratava de um contrato denominado "contrato de prestação de serviços", e também dele constava a estipulação de que «... o segundo contraente se obriga a prestar à 1. ${ }^{a}$ Contraente, após prévia solicitação desta, serviços de Instrutor de Ginástica, preferencialmente em regime de Treino Personalizado (PT)» e, bem assim, «... mediante solicitação da $1 .{ }^{a}$ contraente, realizar trabalhos de pesquisa, preparação e organização de projetos e eventos sobre matérias relacionadas com a sua prestação de serviços ».

Considerando a data da celebração do contrato, o Supremo (como, de resto, as instâncias) elegeu como aplicável a versão do art. $12^{\circ}$ constante do Código de 2003 - treze anos depois da sua revogação, e dez anos depois de reconstruida a presunção como arma de combate à fraude. Beneficiou, de resto, do facto de a Relação ter efectuado um laborioso percurso analítico pelos cinco factores que, cumulativamente, deviam ser provados para que, naquele regime, funcionasse a "presunção" da existência de contrato de trabalho. O exame da Relação tinha concluído que todos os cinco factores estavam verificados, o que o STJ confirmou, não se dispensando, porém, de indagar, com alguma detença, se a Ré tinha logrado a missão impossível de ilidir tal "presunção" — que, como se sabe, era, na realidade, uma absoluta certeza.

Já atrás se referiu este mesmo acórdão, pelo facto de exprimir, a nosso ver, certa incompreensão da natureza e da função da presunção de laboralidade. Com efeito, a construção desta última foi tomada como uma simples derivação do método tipológico utilizado pelos tribunais, destinada, aparentemente, a actuar pela mesma lógica, e aparecendo, em consequência, como um estreitamento (pela redução a cinco índices) da abrangência daquele método.

Por outro lado, foi atribuída à presunção uma função directamente qualificante que ela de modo algum possui: "A Lei faz decorrer do conjunto dos factos descritos nas alíneas deste artigo $12 .^{\circ}$, que caracterizam a relação entre o prestador e o seu beneficiário, um efeito jurídico específico - a existência de contrato de trabalho, ou seja, de uma relação de trabalho subordinado entre as partes envolvidas naquela 
prestação de atividade. Tais factos não operam em abstrato, mas apenas como elementos de caracterização da relação entre a pessoa que presta uma atividade e outra ou outras que dela beneficiam. O efeito jurídico associado pela lei não decorre apenas da verificação destes factos índice, isoladamente considerados, mas da ocorrência do conjunto destes elementos, no contexto mais vasto da relação de prestação de atividade em causa." Essa era, com efeito, a consequência prática do funcionamento da "presunção" regulada na versão de 2003, mas não o "efeito jurídico" visado com uma presunção legal, que seria apenas o da inversão do ónus da prova.

\section{O ARgumento de "EQuilíbrio processual"}

Em apoio da tese que mereceu consolidação no STJ, foi ainda invocado um argumento de equilibrio processual. Encontramo-lo, por exemplo, em acórdão também relativamente recente ${ }^{29}$ : "a presunção de laboralidade é um meio facilitador da prova a favor de uma das partes, pelo que a solução de aplicar a lei vigente ao tempo em que se realiza a actividade probatória pode conduzir a um desequilíbrio no plano processual provocado pela impossibilidade de se ter previsto, no momento em que a relação se estabeleceu, quais as precauções ou diligências que deviam ter sido tomadas para assegurar os meios de prova”. E acrescenta-se: “Tal situação poderia conduzir à violação do direito a um processo equitativo e causar uma instabilidade indesejável em relações desde há muito constituídas."

Relativamente a este modo de ver as coisas, permitimo-nos formular algumas considerações soltas que mais não reflectem senão as nossas dúvidas e perplexidades sobre o assunto.

Em primeiro lugar, cremos dever sublinhar que o apuramento da existência de um contrato de trabalho, quando as características de uma relação de serviço preenchem o essencial desse tipo negocial, não é apenas relevante sob o ponto de vista dos interesses dos contraentes - como parece pressupor-se no argumento de “equilíbrio processual”. Não está

29 STJ 07/04/2018 - P. 1272/16.4T8SNT.L1.S1 (Chambel Mourisco). 
nisso em causa somente a afirmação de certos direitos e vantagens para o trabalhador, e dos correlativos deveres e encargos para o empregador. A aludida qualificação releva, paralelamente, para a realização do interesse público associado à efectivação das normas de todo um sector do ordenamento jurídico ${ }^{30}$.

Esta consideração arrasta-nos para uma reflexão breve acerca da aplicação do art. $342^{\circ}$ do Código Civil, tal como sempre foi feita no âmbito do contencioso laboral. Nunca impressionou ninguém, aparentemente, o facto de que essa aplicação lançava sobre o trabalhador todo o peso da actividade probatória necessária ao preenchimento de um tipo contratual que, por um lado, sempre correspondeu (e continua) à normalidade das relações de serviço em proveito alheio, e, por outro, divide com o tipo contratual contraposto, em que o prestador de trabalho é desprovido de protecção, uma crescente "zona cinzenta", geradora de dificuldades acrescidas de qualificação. O originário desequilíbrio processual daí resultante — irmão dilecto do desnível substantivo próprio das relações de trabalho - nunca parece ter impressionado particularmente os tribunais, em qualquer das instâncias.

A ideia de que a aplicação retrospectiva da presunção de laboralidade é susceptível de acarretar um "desequilíbrio no plano processual" traduz uma preocupação de ordem formal, que carece de verdadeira substância. Não libertando o trabalhador de qualquer encargo probatório, nem “decidindo" por si só a questão da qualificação, a presunção actua, somente, como uma atenuação do desequilibrio processual originário que a aplicação pura e simples do art. $342^{\circ}$ do Código Civil induz.

No fundo, o argumento de "desequilíbrio processual" e de "violação do direito a um processo equitativo" assenta numa ideia de proteç̧ão da confiança que parece difícil de sustentar. Perguntar-se-á, com efeito, que protecção merece a confiança na aparência de um contrato de prestação

30 Este interesse público está bem evidenciado no modo por que se estrutura a acção de reconhecimento da existência de contrato de trabalho, regulada nos arts. $186^{\circ}-\mathrm{K}$ e seguintes do Código do Processo do Trabalho, assim como na associação de uma responsabilidade contraordenacional à responsabilidade civil pelo incumprimento do contrato de trabalho. A este respeito, valerá a pena salientar de novo o facto significativo de a presunção de laboralidade aparecer funcionalmente ligada, no art. $12^{\circ}$ do Código do Trabalho, ao regime contraordenacional aplicável à simulação laboral. 
de serviço cuja realidade, a final, se não consegue $\operatorname{provar}^{31}$. Sabe-se que a caracterização formal de um desses contratos - seja qual for a sua real natureza - é conduzida, na imensa maioria dos casos, pelo beneficiário do trabalho (empregador ou prestatário de serviço). No entanto, a qualificação relevante dele, em cenário litigioso, deverá, naturalmente, assentar na realidade das relações contratuais (nos comportamentos pelos quais os contraentes executam as suas obrigações e concretizam os seus direitos). Parece, assim, difícil atribuir especial consideração a uma postura preventiva do credor do trabalho relativamente à prova futura dos factos caracterizadores do contrato - a não ser na inverosímil perspectiva de se pretender garantir a eficácia dos expedientes simulatórios ao seu alcance.

31 Vale a pena retomar neste ponto as palavras lapidares de Manuel de Andrade, recordadas também no acórdão da Rel. Guimarães atrás citado: a aplicação imediata das leis processuais vale também para o direito probatório material "enquanto regula a admissibilidade das provas de quaisquer factos em geral (sistema probatório geral). Quaisquer expetativas em face da lei anterior não são dignas de proteção. Seria mesmo desonesto o cálculo que alguma das partes, sobre a base do sistema probatório geral anterior, tivesse formado no sentido de se provar um facto não verdadeiro ou de não se provar um facto real". - Noçôes elementares de processo civil, (2ª ed., Coimbra, 1963), 47. 
